\title{
Competitiveness Analysis of Indonesian Banking Industry Based on Corporate Social Responsibility Impacts
}

\section{Lindiawati}

Universitas Hawam Wuruk Perbanas Surabaya, Indonesia

\begin{tabular}{ll}
\hline ARTICLE INFO & ABSTRACT \\
\hline Publication Online: & $\begin{array}{l}\text { Corporate Social Responsibility (CSR) has been becoming more attention for both companies and } \\
\text { consumers. People are more aware of giving consideration on what companies have been doing for } \\
\text { public as the representative of their responsibilities, and they use this to make buying decision and } \\
\text { producing word-of-mouth. Corporate Social Responsibility has also been involved in banking } \\
\text { industry since bank is an industry that is considered fragile or very easy to be affected by publis } \\
\text { psychology leading bank customers then rush during a negative issue impacting the bank industry. } \\
\text { By the government regulation pushing the banks to implement CSR, the kinds of CSR activities } \\
\text { must reflect what banks wanth to achieve. Based on some studies on CSR impacts, it has been } \\
\text { identified that the impact of CSR activities can be classified into four categories namely: } \\
\text { phylanthophy, promotion, business impact, and mindset change. By knowing the map of the banks' } \\
\text { CSR activities based on those four categories, it can be concluded the competitiveness of the bank } \\
\text { especially from the perspective of their social exposures. The result shows There are four banks that } \\
\text { have well implemented CSR in term of that they have many CSR activities and whose impact level s } \\
\text { are high. Three of of the four banks, have completed CSR whose impacst are complete, namely } \\
\text { philanthropy, promotion, Business Impact, and Mindset Change. }\end{array}$ \\
Corresponding Author: \\
Lindiawati
\end{tabular}

KEYWORDS: Corporate Social Responsibility, CSR Impacts, philanthropy, promotion, business impact, mindset change.

\section{INTRODUCTION}

Corporate Social Responsibility (CSR) has been becoming more attention both for the companies and consumers. People are more aware of giving consideration on what companies have been doing for public as the representative of their responsibilities, and they use this to make buying decision and producing word-of-mouth (Perez and Del Bosque, 2015; Marinova, 2013). In Indonesia, conventional banks are grouped into four groups namely BUKU 1, 2, 3 and 4 which each refers to the number of their first capital and the coverage of the business operation. BUKU 4 is the highest level followed by BUKU 3, 2 and 1. Corporate Social Responsibility in banking industry has been encouraged to be implemented by the government regulation leading for first two grouping of banks based on capital having obligation to do and must report in their websites. Anyhow the last two groups of the banks -out of four groups- has the obligation to implement CSR but does not obliged to report in their website.

Corporate Social Responsibility (CSR) activities implemented in banking industry lead to some impacts either for external or internal targets. To measure the impact of CSR, referring to the summary of some studies offering to four main CSR impacts namely phylanthopy, promotion, business impact, and mindset change (Solihin, 2009; Zairi \& Peters, 2002). These impacts, although have been measured differently, but it showed patterns in different countries. Some previous researches conducted in North European countries, as developed countries, found CSR impact leading people to experience mindset change. While in India, CSR activities were more focused on improving public facilities which is the area of phylanthropy. In Indonesia's banking industry the percentage of CSR activities led to mindset change was relatively not dominant namely only $15 \%$ (Lindiawati, Suhartono, 2017a).

Referring back to the four categories of CSR impacts which are phylanthrophy, promotion, business impact, and mindset change, what does CSR mean for the banks in substance? The answer is focused on the concept of CSR that should offer a healthy company-society cycle that means that when companies contribute fund in the forms of CSR, it proportionally must be beneficially giving values back to the companies in order they can contribute sustainabily back to the society (Craven, D.W. , Piercy, 
2013; Kotler, P. dan Armstrong, 2016; Pérez \& Del Bosque, 2015). In strategic management point of view, companies must think of social responsibility programs in their strategic planning since these programs are fruitful sustainably in the long run. Social responsibility activities are weapons trigerring and leveraging people positive emotion to positively response and support back the companies as CSR providers.

In Indonesia's banking industry, there are four categories of banks based on their initial capital set up and their operation level, for which the category uses the term called BUKU (BUKU stands for Bank Umum Kelompok Usaha) meaning Commercial Banks categorized on Operation Levels. The categories are $B U K U$ 1, 2, 3 and 4. Banks of $B U K U 4$ consists of the big four in Indonesia that can operate overseas namely BRI, Mandiri Bank, BCA, and BNI; but since 2017 one more bank of CIMB Niaga has been included into this group (anyhow, the analysis was based on the inclusion of CIMb Niaga bank in the category of BUKU 3). Banks of BUKU 3 consists fifteen banks over 2015-2018, but getting more members in the following years. These two categories are banks that already go public, so they report annualy and upload to their websites. As the extension of the banks' annual report, CSR report is attached to it. So, the CSR activities of the banks under these two categories are already prepared and well reported. While the report of the other two catgeories left which are BUKU 2 and BUKU 1 are not available in their website.

What does CSR mean for companies? Referring to the Strategic Management perspective, CSR activitieas are very important and must be learnt in detail leading to the impacts potentially resulted. That is referred to the planning; anyhow from the competition area, a concept of Dynamic Strategic Group (DSG) gives ant idea for companies to always be aware of their competitors. DSC groups companies based on certain criteria and it is used to anlyze the competition within an industry or competitive analysis (Desarbo, Grewal, \& Wang, 2009). With the help of statitistic tools even those the simple one, the result can be a meaningful competitive dynamic mapping.

By the rational consideration of CSR importance and the strategic competitive analysis, this study is aimed at identifying the CSR activities over 2015-2018 of the fifteen banks within the category of BUKU 3 by which the impacts of the CSR is identified and analized. The output of this research is the mapping of DSG based on CSR impacts and sectors.

\section{THEORETICAL FRAMEWORK}

\subsection{Dynamic Strategic Group (DSG)}

Dynamic Strategic Group (DSG) referred to analytic groupping of companies in an industry based on certain criteria. The criteria can be similarity or difference, how long having been in the industry, or other characteristics (Adejuwon, 2014; Desarbo et al., 2009). Dynamic Strategic
Group is often used to conduct a competitive analysis with the result of competitive dynamics mappipng. This mapping can be used to predict the strategy of the competitor in a more focued way depending on the evaluated criteria. In other word, this mapping can be functioned to conduct a benchmaark (Bikker \& Haaf, 2002). The steps of the analysis are a) Decide who the members of the industry to analyze are, b) Decide the criteria or the dimension evaluated. Usually key success factors and performance measurement are dominantly analyzed.

\subsection{Competitive Dynamic Theory}

Competitive Dynamic Theory refers to broader framework of company interaction in an industry in the context of competition. By competitive dynamics, competition among companies is studied as action and reaction between the competing companies, and it is amied at a) predicting competitive behavior, b) being aware of AMC model which is Awareness, Motivation, Capability) meaning that when a company is being atttacked by other company, there will be an awareness of being attacked; motivation means that the attacked company will make a response of defending or attacking back; and capability means that in facing the attack, the company must be able to confirm themselves if they have the strength to attack back, c) Changing strategic formulation into strategi implementation .

Operationally, competitive dynamic theory refers to some assumptions as follows a) Competition is dynamic and interactive , b) This theory focuses on actual actions of the companies, c) In a competition, there must be a pair of headto-head companies which are equally strong in the industry. Anyhow, in a competition, relativity between companies normally happens meaning that if company $\mathrm{Y}$ thinks company $\mathrm{X}$ is its rival, but $\mathrm{X}$ does not necessarily considers that $\mathrm{Y}$ is its rival (Sukoco, 2014)

\subsection{Integrative Competitive Analysis}

In business knowledge wheter marketing, strategic management, or other business knowledge areas, thinking about competition must involve both internal and external environments. A research model conducted by Khan (2010); Sukoco, (2014) explained that a research model on competition should integrate external and internal factors namely market commonality and resource similarity. Market commonality refers to how strong our competitors and how they share their position with our company in the industry; while resource similarity looks into comparable strategic resource belonging to the competitors in term of number and kind (Barney, 1991; Gimeno \& Woo, 1996). Since every company is unique dan has different resources, so the competition tension among companies is relative one to another. This logic context is called relative competition.

\subsection{Corporate Social Responsibility (CSR)}

Corporate Social Responsibility (CSR) is a construct developing the relationship between companies and their 
environment. CSR is defined as all companies' activities involving their society, environment, and showing interaction between companies and their stakeholders (Yip $\&$ Bocken, 2017). From the perspective of strategic management, in formulating long term objectives, companies must consider the interest of their society that can be accommodated by the companies. This means that the strategic planning of companies should involve their stakehorders(Pearce, John A. \& Robinson, 2003). Internally, CSR is also considered to be able to improve staff retention rate (Pérez \& Del Bosque, 2015). In term of stakeholders, CSR is related to four stakeholders posing in the dimension of CSR which are customer, employee, shareholder, and government. The companies must be able to map which stakeholder should be in the priority of their CSR (Pérez \& Del Bosque, 2015) (Lindiawati, Suhartono, 2017b). In banking industry, the scrutinity in learning the priority of the stakeholder is framed by the solid regulations pursuing the implementation of reportig banks' CSR activities. Banks' products are the same, among banks within the industry may refer to each other as what is called as reference theory. By facing market commonality and government regulation on CSR, banks must be aware of maneuvering into correct differention of their strategies.

Stakeholders in banking industry ranges from customers, staff, supplier, society, government and shareholder (Valor, 2005) that are further categorized into internal and external stakeholders. These groups are getting smarter and are more aware of considering moral values in making decision. So, CSR is a good way of leveraging all banks' efforts for the public and customers to be positively responded (Sen \& Bhattacharya, 2001).

\subsection{Sectors and Impacts of CSR}

CSR sector is area of CSR that the banks implement which by several studies has been summarized in a shortlisted sectors namely health, education, environment, employee development and relation, public donation, and product development. Furthermore, CSR is also categorized based on its impact which is the benefits of the CSR activities either for external or internal parties. Solihin (2009) categorized the CSR impacts into four categories including philanthropy, Promotion, Business Impact, and Mindset Change.

Philanthropy refers to giving away of what the banks are able to do for the intended parties. Since the substance is giving and helping, the benefit or impact level of philanthropy is considered the lowest. Philanthropy is widely needed especially in a develping countries since in these countries the social condition of the society and often the environment still need a one way giving meaning the giving that does not have any impact back to the giver nor to the rest of the society beyond the CSR target. The most common of philanthropy in Indonesia is for helping the victim of the damage of the effect of natural disasters. In this

case, the banks giving the donation do not expect the benefit back to for them since the giving is usually done immediately when asked to give and the aim is to give aid for the society problems.

CSR impact for promotion has the widest coverage since the other three categries of CSR impacts namely philanthropy, business impact, and mindset change may also include promotion aspect. For example, when a banks gives donation for disaster victims, the banks still get the benefit of being promoted. Although the victims do not give the attention o which bank helping them, but people outside this situation potentially give attention and sympathy when they get the publication the the bank's donation from mass media.

Compared with promotion, business impact refers to CSR activities whose impacts have beed thourougly designed to be able to influence the sustainability of the banks business directly or indirectly. Indirect impact can be exemplified as when a bank give a group of fishermen boats in order they can get more fish, then when they get better fish selling and get more money, they can save their money in the bank having given them boats. While direct impact can be exemplified when a bank come to a school then explain the benefit of saving money for their future life while the bank has already provide the students with a mobile bank car to which the student can immediately open a bank account with this bank. This CSR automatically gives a direct business ipact to the bank in the form of the added number or account opened by the students at the same time at school.

The last category of CSR impact is the mindsetchange whish is considered the highest level of CSR impact. It is cosidered so since the impact of changing or shifting the way of people think is not that easy and the efforts need a high commitment both from the company (the bank) and the society. When a bank sponsors an anti-cigarette activity, the effect of changing people's mindset is high, although it does not have any business impact at all.

\section{RESEARCH METHOD}

\subsection{Research Design}

This research is a descriptive research that comprehensively describes CSR activities having been implemented by fifteen banks under the category of conventional banks of BUKU 3 over 2015-2018. Descriptive research is a research describing a phenomenon with a specific purpose (Malhotra, 2010). The CSR activities of the fifteen banks are reported annually within the banks annual report that can be downloaded from their websites. The data used in this research is seconder data since the data is taken from the banks' annual report. The analysis used is content analysis conducted by identifying CSR activities implemented by all the fifteen banks using the four CSR impact categories namely philanthropy, promotion, business impact, and mindset change. The identification is done by using the 
modus or frequency of CSR activities and presented in the percentage. Then by using Microsoft Excel 2010, the modus data was visualized in the form of bar charts.

\subsection{Population, Sampel and Sample Technique}

The population of this research is conventional banks which are obliged to report their CSR activities in their websites which are banks under the category of BUKU 4, BUKU 3, and BUKU 2. Anyhow the sample used is those of the member banks of BUKU 3. The consideration of only using BUKU 3 banks is that this group of banks has similar characteristics in term of initial capital and operation coverage as stated Indonesia Central Bank Regulation of No 14/26/PBI/ 2012 on December 27, 2012 that banks of BUKU 3 refers to the following condition: a) Initial capital of 5-30 trillions, b) Product and operation coverage is that the banks can run the business in domestic and foreign currencies, and involve twenty five percent to financial institution in domestic or foreign institution of Asia wide.

The logical consequence of the codition, each group of BUKU 2, BUKU 3, and BUKU 4 has their own characteristics. Banks of BUKU 4 are the big four banks having been establishing their market position and three of them are state-owned and their CSR activities are significantly wide in. Banks of BUKU 2 are banks with few CSR activities and often do not make specific report of their CSR. So, the sample used is banks of BUKU 3 which have not to gapping CSR activities compared with those two other groups of banks.

\subsection{Data and Method of Data Collection}

The data of this research are secondary data got from the annual report of banks of BUKU 3.The data are the result of the identification of all CSR activities that are counted and categorized based on the impact category which are philanthropy, promotion, business impact, and mindset change. This modus data or frequency then are percentaged and visualzed in the graph.

\section{DATA ANALYSIS AND DISCUSSION}

\subsection{Data Analysis}

Content analysis was done to explore the CSR activities of the fifteen banks under the category of BUKU 3. The analysis was conducted by identifying the CSR activities based on the four CSR impacts categories namely philanthropy, promotion, business impact, and mindset change. How to categorize is referred to the following conditions: a) Philanthropy is identified with the condition of as if the CSR activities is giving away something to society or internal stakeholder; and philanthropy activities are automatically considered as promotion; b) Promotion is identified with the condition of as all CSR activities which are philanthropic, having business impact and causing mindset change are automatically having promotion impact, and CSR activities targeted for internal stakeholders are not considered a s promotion; c) Business Impact is identified with the condition of as referred to CSR activities having impact to banks' operatio and performance; these activities are automatically having business impact; d) Mindset Change is identified with the condition of as referred to CSR activities that can be able to change or shift the people mindset on something wrong happening on human or environment; some of the activities are having business impact to the banks. After the CSR activities were identified using those four CSR impact categories, the modus data then were percentaged as in Table 4.1.

Tablel 4.1. The Tabulatioan of CSR Impacts of Banks of BUKU 3

\begin{tabular}{llllll} 
No & Banks & Philantropy & Promotion & $\begin{array}{l}\text { Business } \\
\text { Impact }\end{array}$ & $\begin{array}{l}\text { Mindset } \\
\text { Change }\end{array}$ \\
\hline $\mathbf{1}$ & OCBC & 15 & 15 & 26 & 12 \\
2 & MIZUHO & 3 & 4 & 0 & 1 \\
3 & BJB BANK & 10 & 10 & 0 & 0 \\
4 & DANAMON & 3 & 4 & 0 & 0 \\
5 & BTPN & 0 & 6 & 0 & 0 \\
6 & BUKOPIN & 14 & 14 & 24 & 2 \\
$\mathbf{7}$ & PANIN & 3 & 3 & 0 & 0 \\
8 & CIMB NIAGA & 10 & 17 & 2 & 0 \\
9 & BTN & 3 & 7 & 0 & 0 \\
10 & SUMITOMO MITSUI & 2 & 3 & 0 & 0 \\
11 & MEGA & 6 & 11 & 1 & 3 \\
12 & PERMATA & 11 & 11 & 0 & 0 \\
13 & MAYBANK & 21 & 33 & 20 & 5 \\
14 & DBS & 1 & 14 & 1 & 2 \\
\hline
\end{tabular}




\begin{tabular}{llllll}
15 & UOB & 3 & 7 & 0 & 2 \\
& TOTAL & 105 & 159 & 74 & 27 \\
& $29 \%$ & $44 \%$ & $20 \%$ & $7 \%$ \\
\hline
\end{tabular}

Source: Banks’ Annual Report over 2015-2018 (Identifiied by Researcher)

These figures then visualzed in the form of graph to easily catch the substance of the data in reflecting the kinds and the impacts of the CSR activities of the fifteen banks. From this resul it is known that some banks shows a similar trend of having the number (the kinds) of CSR activities. Then when this graph is viewed in more individual impacts then it is known that there are some groups of banks dominantly are focused on each of CSR impact It can be viewd as in Figure 4.1 .

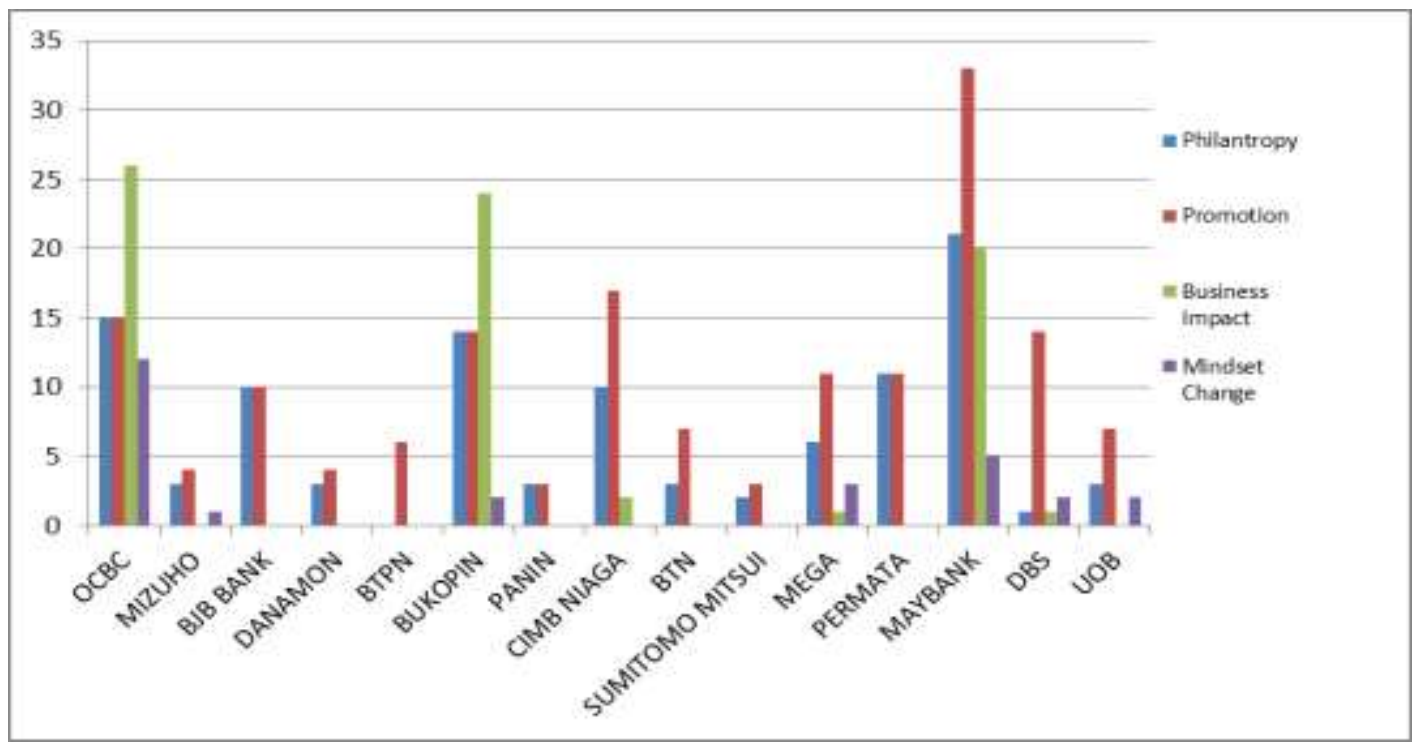

Source: Banks’ Annual Report over 2015-2018 (Identified by Researcher)

Figure 4.1: CSR Impacts of Banks under BUKU 3 Category

The graph shows that the pattern of Banks having well implemented CSR with which the impact levels have also been represented. Based on the graph, there are four banks that have well implemented CSR in term of that they have many CSR activities, namely OCBC-NISP, BUKOPIN, CIMB Niaga, and Maybank. Three of of the four banks, have completed CSR impact (philanthropy, promotion, Business Impact, and Mindset Change). Those three banks are OCBC-NISP, BUKOPIN, and Maybank; while CIMB Niaga has no mindset-change impact. This resultis is line with the quality of reporting CSR activities in the annualy report of the banks. It comes so, since when doing the identification thoroughly into the detail of the annual report of the banks, it showed that the banks that reported their CSR activities in a complete and detailed way were also those four banks.

The data can also be used to know which bank that has high CSR impact for their business sustainability. This impact is very important for the long run business of the CSR giver (banks) since CSR activities with this business impacts will in the future give value back to the banks. This is like a cycle of CSR and CSR Value back for the banks.

The trend can be viewed by looking at the graph above or by mapping the number of CSR activities of all banks in term of CSR impact. This can be seen from the following Table 3.2. The mapping is done by making the range of the number of CSR activities using researcher's own judgement as follows: (1) Very Low (the kinds of CSR Activities CSR: $0<X<5$ ); (2) : Low (the kinds of CSR Activities CSR: $5 \leq X<10$ ); (3) : High (the kinds of CSR Activities CSR: $10 \leq X<15)$; (4) : Very High (the kinds of CSR Activities $: \geq 15$ )

From the mapping in Table 3.2, it can be concluded that: a) OCBC-NISP bank, Bukopin, CIMB Niaga, and Maybank implemented CSR whose impacts have already been very high, in which OCBC-NISP has very good CSR impact for philanthropy, promotion, and business impact, while Bukopin is in business impact, CIMB Niaga is in philanthropy, promotion, and business impact; b) OCBCNSP and Maybank has similar map which have high impact in philanthropy, promotion, and business impact, c) Anyhow, OCBC-NISP has more CSR activities to help change the society's mindset change that if it refers back to the raw data what OCBC-NISP was doing in over 20152018 fell in two areas namely environment care and education area. 
Table 3.2. The Mapping of Banks' CSR Activity Impacts

\begin{tabular}{|c|c|c|c|c|}
\hline BANK & Philantropy & Promotion & Business Impact & Mindset Change \\
\hline OCBC NISP & 4 & 4 & 4 & 3 \\
\hline MIZUHO & 1 & 1 & 1 & 1 \\
\hline BJB BANK & 3 & 3 & & \\
\hline DANAMON & 1 & 1 & & \\
\hline BTPN & & 2 & & \\
\hline BUKOPIN & 3 & 3 & 4 & 1 \\
\hline PANIN & 1 & 1 & & \\
\hline CIMB NIAGA & 3 & 1 & 1 & \\
\hline BTN & 1 & 2 & & \\
\hline \multicolumn{5}{|l|}{ SUMITOMO } \\
\hline MITSUI & 1 & 1 & & \\
\hline MEGA & 2 & 3 & 1 & 1 \\
\hline PERMATA & 3 & 3 & & \\
\hline MAYBANK & 4 & 4 & 4 & 1 \\
\hline DBS & 1 & 3 & 1 & 3 \\
\hline UOB & 1 & 2 & & 1 \\
\hline
\end{tabular}

Note: (1) Very Low (Kinds of CSR Activities CSR: $0<\mathrm{X}<5$ ); (2) : Low (Kinds of CSR Activities CSR: $5 \leq \mathrm{X}<10$ ); (3) : High (Kinds of CSR Activities CSR: $10 \leq X<15$ ); (4) : Very High (Kinds of CSR Activities : $\geq 15$ )

Source: Banks’ Annual Report over 2015-2018 (Identified by Researcher)

In environment area, this bank stated in their repost that they were committed not to fund projects that damage environment. Furthermore they issued internal policy for paperless system, pro-teller paperless system, car pooling and shutte bus to save energy, on-meeting facility to economize space, air conditioner usage, electricity, and fuel; reduced the use of plactic bottled-mineral water, automatic water tap to economize water usage, the use of LED economic bulp.

In education area, OCBC-NISP bank implied financial literation education 'Smart Financial Program' for students of Junior High School and Senior High School, created program of 'I Love Science' for elementary students, conducted One-Day Workshop (ODW) for university students about Banking Overview which since 2008 had been 3,000 students involved, conducted Field Trip for kindergarten students, and conducted Young Entrepreneurship Spirit (YES) Competition since 2013 for university students to create social entreprenersip

What was reported by the fellow bank, Maybank, in implementing their CSR programs whose impacts were in changing-mindset fell in the areas of environment especially for internal policy which were paperless-account opening system, electricity economization; while programs referred to external stakeholders were setting some automated teller machines using solar energy (operated in Bali, since 2012), e-statement for bank customers (since 2012), and credit release for environment-friendly projects only.

\section{CONCLUSION}

Based on the modus data resulted from the identification of the CSR activities based on their impacts, it can be concluded as follows:

a. There are four banks that have well implemented CSR in term of that they have many CSR activities, namely OCBC-NISP, BUKOPIN, CIMB Niaga, and Maybank

b. Three of of the four banks, have completed CSR whose impacst are complete, namely philanthropy, promotion, Business Impact, and Mindset Change.

c. Those four banks (in no 1) have implemented CSR whose impacts have already been very high.

d. Out of the four banks, OCBC-NSP and Maybank has similarity in having high impact in philanthropy, promotion, and business impact

e. Referring to on (d) anyhow, OCBC-NISP has more CSR activities to help change the society's mindset change. This is what other banks haven't achieved yet.

\section{REFERENCES}

1. Adejuwon, O. O. (2014). Regulation and strategic group dynamics of the Nigerian telecommunications industry. African Journal of Economic and Management Studies, Vol.(No 2), 5. P. http://doi.org/10.1108/AJEMS-08-2012-0053

2. Barney, J. (1991). barney1991-competitive advantage.pdf.

3. Bikker, J. A., \& Haaf, K. (2002). Competition , concentration and their relationship : An empirical 

analysis of the banking industry, 26, 2191-2214.

4. Craven, D.W. , Piercy, N. F. (2013). Strategic Marketing (10th ed.). Singapore: McGraw Hill.

5. Desarbo, W. S., Grewal, R., \& Wang, R. U. I. (2009). Dynamic Strategic Groups: Deriving Spatial Evolutionary Paths, 1439 (May), 14201439. http://doi.org/10.1002/smj

6. Gimeno, J., \& Woo, C. Y. (1996). Hypercompetition in a Multimarket Environment: The Role of Strategic Similarity and Multimarket Contact in Competitive De-Escalation, (June 2016).

7. Khan, H. U. Z. (2010). The effect of corporate governance elements on corporate social responsibility (CSR); reporting: Empirical evidence from private commercial banks of Bangladesh. International Journal of Law and Management, 52(2), 82-109. http://doi.org/10.1108/17542431011029406

8. Kotler, P. dan Armstrong, G. (2016). Principles of Marketing. USA: Pearson.

9. Lindiawati, Suhartono, T. S. (2017a). The Impact of Islamic Banks' Corporate Social Responsibility on Its Customers' Loyalty. International Journal of Current Advanced Research, 6 (8).

http://doi.org/http://dx.doi.org/10.24327/ijcar.2017. 2346.0005

10. Malhotra, N. K. (2010). Marketing Research (6th ed.). Tokyo: Pearson.

11. Marinova, N. (2013). Marketing Ethics and Social Responsibility. Trakia Journal of Sciences, 11(11), 535-538. Retrieved from http://www.uni-sz.bg

12. Pearce, John A. \& Robinson, R. B. (2003). Strategic Management: Formulation, Implementation, and Control. New York: McGraw Hill.

13. Pérez, A., \& Del Bosque, I. R. (2015). The formation of customer csr perceptions in the banking sector: The role of coherence, altruism, expertise and trustworthiness. International Journal of Business and Society, 16(1), 75-94.

14. Sen, S., \& Bhattacharya, C. B. (2001). Doing Better? Social Lead Consumer Reactions Doing Corporate Responsibility, 38(2), 225-243.

15. Solihin. (2009). Corporate Social responsibility: From Charity to Sustainability.

16. Sukoco, B. M. (2014). Brand Community. Surabaya: Erlangga University Press.

17. Valor, C. (2005). I ( 2005 , (Cc), 191-212.

18. Yip, A., \& Bocken, N. (2017). Sustainable Business Model Archetypes for the Banking Industry. Journal of Cleaner Production. http://doi.org/10.1016/j.jclepro.2017.10.190

19. Zairi, M., \& Peters, J. (2002). The impact of social responsibility on business performance. Managerial Auditing Journal, 17(4), 174-178. 